\title{
Attorney's Independence in Implementing Law Enforcement Duties: Challenges and Development
}

\author{
Khunaifi Alhumami*, Marthen Arie, Musakkir, Slamet Sampurno \\ Faculty of Law, Hasanuddin University, South Sulawesi, Indonesia \\ * Corresponding author
}

\begin{abstract}
As part of the implementer of judicial power, the attorney must also obtain a guarantee of independence in exercising its duties and functions. Without an independent attorney, it is impossible for an independent judicial authority to be realized. This research is descriptive with normative-juridical type. The approaches used were statutory, conceptual, analytical and case, and comparative by using deductive and inductive reasoning. The results show that implementing the attorney's independence must be realized in the form of an independence guarantee for the executing apparatus (prosecutor and attorney general) in exercising law enforcement duties. It is not in the form of institution independence as happened during the guided democracy up to now. The establishment of the attorney as an independent institution apparently is not directly proportional to the independence in the implementation of duties and functions in the field of law enforcement that is right under the authority of the President. When the independence of the attorney is implemented in the form of individual independence of the prosecutors and the Attorney General, it brings positive implications for the implementation of law enforcement duties.
\end{abstract}

Keywords: Attorney; Prosecutor; Legal Structure; Independence

DOI: $10.7176 / J L P G / 95-14$

Publication date:March $31^{\text {st }} 2020$

\section{Introduction}

A main instrument of the constitutional State is the guarantee of the implementation of an independent judiciary and free from other powers in order to enforce a fair legal process to all citizens. ${ }^{1}$ In essence, the power is not only exercised by the judiciary that refer to the Supreme Court and the Constitutional Court but also by other bodies, one of them is attorney. As part of the implementer of judicial power, the attorney must also obtain a guarantee of independence in exercising its duties and functions. Without an independent attorney, it is impossible for an independent judicial authority to be realized. Without an independent judicial power, it is impossible for the legal supremacy to be realized. In other words, an independent attorney also contributes to the realization of the legal supremacy which has a strong influence on the realization of democratic statehood. By the good legal supremacy, it is expected to be able to support the creation of a democratic political process so that it can produce professional leaders with integrity. In addition, a good legal supremacy is ultimately expected to bring about justice, legal certainty, and benefits for society.

The independence of the attorney in implementing law enforcement has actually been regulated in Article 2 paragraph (2) of Act No. 16 of 2004 concerning the Attorney of the Republic of Indonesia. In a quo article states that State authority in the field of prosecution is exercised independently. It means to be free from the influence of government and other powers. However, this is often doubted by the public, because of the position of the Attorney General as the President's Assistant who can be dismissed at any time by the President. The position of the Attorney General as the President's Assistant has been going on since President Soekarno applied the concept of integrated democracy and rejected the trias politica by making all State officials including the Attorney General as a Minister that basically as the President's Assistant. After the Attorney General is appointed as minister, the attorney is excluded from the Department of Justice and stands

\footnotetext{
${ }^{1}$ Independent judicial power as a main instrument of the constitutional State was stated by Van der Pot Donner who represented the experts from the civil law system. See Marwan Effendy, Kejaksaan RI: Posisi dan Fungsinya dari Perspektif Hukum, Jakarta: Gramedia Pustaka Utama, 2005, p. 23. While, a fair legal process as one of the important elements of the constitutional State was put forward by Albert Venn Dicey who represented the experts of the common law system. See Jimly Asshiddiqie, Konstitusi \& Konstitusionalisme Indonesia, Jakarta: Konstitusi Pres, 2005, p. 152
} 
alone as the Department of Attorney or non-departmental institution.

Actually, the independence of the institution was not followed by the independence of the implementing apparatus because as minister or President's assistant, the Attorney General can be dismissed at any time by the President. The history of law-enforcement in Indonesia shows that since the Attorney General was appointed as Minister or President's Assistant, the independence of the attorney was weak and law enforcement has not proceeded professionally. Historically, the decline of law enforcement in Indonesia by the attorney was in line with the discontinuance of Attorney General Soeprapto and the shift of the attorney to the court authority. ${ }^{1}$ At the time, the leadership of the attorney began from politicians and the military, and the attorney was under executive and military control. According to Gunawan Muhamad, the most dilapidated in the history of modern Indonesia over the past 30-40 years is the breakdown of the law. During the guided democracy, the law was defeated by revolutionary politics. Revolution is put above all, and law is not considered as important thing. Judges can be bribed and lawyers become brokers for bribes. ${ }^{2}$ Such law enforcement apparently has not stopped after the new order was replaced by the reform order and now it should be elaborated more deeply related to the independence of the attorney institution. This research is descriptive with normative-juridical type. The approaches used were statutory, conceptual, analytical and case, and comparative by using deductive and inductive reasoning.

\section{The Challenges of Attorney's Independence: Comparative Study}

Literally, independent means not subject to the power or influence of other parties. In the Black's Law Dictionary, independent means "not subject to control or influence of another." ${ }^{3}$ In order not to submit to the power or influence of other parties, it must have the power to resist intervention from other parties. Without having the power to resist, it is impossible for someone to maintain their independence. According to Artidjo Alkostar, independence contains 2 (two) meanings, namely institutional and functional independences. Institutional independence means an independent institution and must be free from intervention by another outside the system. While, functional independence is independence in exercising their duties and functions. ${ }^{4}$ A similar opinion was expressed by David Phillip Jones who stated that independence could involve individuals or institutions in relation to status or relations with another. ${ }^{5}$ Therefore, independence encompasses independence or individual or institutional freedom against the influence of external parties.

The issue of independence has a very significant role in realizing free and impartial judicial authority. This is not only a matter for judges but also concerns prosecutors, because both are executors of judicial authority. Even in France, prosecutors and judges are classified in one level, namely the magistrate. Without an independent prosecutor, it is impossible for a judge to exercise his duties and functions independently. It because the criminal case examined by the judge is very dependent on the prejudgment made by the prosecutor. Thus, the prosecutor also needs to guarantee his independence in exercising his duties and functions.

In fact, the matter of the prosecutor's independence has been a serious discussion at various meetings of European countries, including The European Status of Justice 1993. The meeting encourages discussions about the prosecution system in the State authority structure. Section 9.1 the Resolution of the European Status of Justice asserts "self-government in prosecution creates an essential instrument of judicial power independence". Thus, the ability to decide independently in a prosecution body is an essential instrument in

\footnotetext{
${ }^{1}$ Daniel S. Lev, Hukum dan Politik di Indonesia, (Translated: Nirwono and A.E. Priyono), Jakarta: LP3ES, 1990, p. 203.

${ }^{2}$ Goenawan Mohamad (ed), "Menyalahkan Lilin Dalam Kegelapan”, Jakarta: ISAI, 1999, pp. 214-215.

${ }^{3}$ Bryan A. Garner, Black's Law Dictionary, ST. Paul: West Group, 2009, p. 838

${ }^{4}$ Artidjo Alkostar, "Menjaga Keselarasan antara Moral dan Hukum; Reformasi Peradilan di Indonesia." A Paper of National Seminar 'Dialectics Between Law and Moral; A Lesson of Legal Reform in Reform Era, in the 68 $8^{\text {th }}$ Anniversary of the Islamic University of Indonesia on April 29, 2011 at Auditorium Kahar Mudzakkir, Islamic University of Indonesia, Yogyakarta, 2011, pp. 7-8.

${ }^{5}$ David Phillip Jones, “Recent Developments in Independence and Impartiality," Canadian Journal of Administrative Law \& Practice, 2002, Accessed on http://www.westlaw.com, 08 Nopember 2019.
} 
realizing independent judicial power. However, the implementation of the attorney's independence in each country is realized differently. In outline, it is usually realized in the form of appointment procedures; dismissal; and the term of the Attorney General; and the organizational structure of the attorney.

In the United States (Anglo America), the independence of the prosecution is implemented through the procedure for selecting prosecutors through the General Elections. The State prosecutor (District Attorney) is elected directly by the people of the State, while the federal prosecutor (US's Attorney) is elected by senators in the congress. This shows the prosecutors in the United States are political positions, therefore the position of prosecutors in the United States is very strong. As a political figure, a prosecutor must be able to maintain their integrity and professionalism so that their electability is maintained in the eyes of the public. Not infrequently then they are elected to become Governor, or even become President like Bill Clinton, who was the Governor and Attorney General in the State (Arkansas). ${ }^{1}$ The independence of the prosecution in the United State is also supported by a private prosecutor system. The injured party can appoint a private party to conduct investigation and prosecution if they are unsure of the performance of the State prosecutor. This system can encourage prosecutors to act professionally because there are "comparative prosecutors" serve as a means of social control for the public to oversee the duties of State's prosecutors.

In Malaysia (Anglo Saxon), the State's Peguan (Attorney General) was appointed by "Yang di-Pertuan Agong" as proposed by the Prime Minister. Those who can be appointed as State's Peguan are who eligible to become judges of the Supreme Court (MA). ${ }^{2}$ He holds position for as long as is permitted by Yang di-Pertuan Agong and cannot be dismissed, unless there is a good reason. The procedure for dismissal of the Attorney General is the same as the Supreme Court judge. ${ }^{3}$ According to Mohomad Sophian, prosecutor at the position of Peguan Negara Kuala Lumpur - Malaysia's Attorney General was directly under the Prime Minister, but the one who appointed him was not the Prime Minister but Yang Di-Pertuan Agung (the King) as proposed by the Prime Minister. After being appointed, they cannot be dismissed at any time until retirement age (60 years). Dismissal and substitution of the Attorney General before retirement age may only be done through a tribunal examination by the Supreme Court. Without the decision of the Tribunal, anyone cannot dismiss the Attorney General. ${ }^{4}$

In the Netherlands (Continental Law), the Attorney General is appointed for life as a judge (Supreme), although it is also possible that the law determines a certain age limit. ${ }^{5}$ According to $\mathrm{R}$. Tresna that the reason the Attorney General was appointed for life is because it is not impossible that at one time he had to act against the Minister of Justice (who is the direct superior of the Attorney General). In addition, do not let the Attorney General be dismissed for reasons of opportunity or political considerations. In the interest of the State, the position of the Attorney General must not be paralyzed, if at any time he must carry out his obligations by taking action against those who are in power. ${ }^{6}$

\section{Implications of Attorney Independence}

In relation with two forms of implementation of the prosecutors' "independence", Andi Hamzah distinguishes between independent and stand alone. Standalone means institutionally the attorney is separate from other institutions so that it stands alone as an institution as is currently happening in Indonesia. While, independent means that the prosecutor is autonomous in implementing his duties and functions, free from the influence of other powers and leaders, there is no exposure before the trial and there is no "harmonious". Prosecutors are considered as doctors who practice based on their profession. ${ }^{7}$ This means that the independence is in the

\footnotetext{
${ }_{1}^{1}$ R.M. Surachman, Mozaik Hukum I 30 Bahasan Terpilih, Jakarta: CV. Sumber Ilmu Jaya, 1996, pp. 88-89.

${ }^{2}$ Article 145 paragraph (1) the Malaysian Constitution.

${ }^{3}$ Article 145 paragraph (5) and (6) the Malaysian Constitution.

${ }^{4}$ Interview with Mohamad Sophian on 13 March 2017 in Denpasar.

${ }^{5}$ Article 167 paragraph (2) Grondwet Belanda. See Andi Hamzah, Op. Cit., p. 66.

${ }^{6}$ R. Tresna, Loc. Cit.

${ }^{7}$ Andi Hamzah, "Posisi Kejaksaan dalam Sistem Ketatanegaraan RI”, National Symposium "Hari Bhakti Adhyaksa". Held by Pusat Litbang Kejaksaan Agung. Jakarta: 20 July 2000, p. 3.
} 
"person" and not the institution. The author agrees that independence must be aimed at the implementation of law enforcement tasks, not institutional independence. The prosecutor' office may not be independent because it is part of the executive bodies, but in implementing its law enforcement duties it must be independent because it is part of the judicial authority.

The reluctance of the Presidents to exclude the Attorney General from the cabinet arrangement because it was comfortable using the prosecutor hands as a bat. ${ }^{1}$ The shift in attorney independence has implications for many aspects. The important aspects that changed due to the influence of the shift include the organizational structure of the prosecutor's office, the individual autonomy of prosecutor and the independence of the prosecutor in implementing law enforcement duties.

The independence of the attorney and the shift of the attorney to the realm of the pure executive, also affect the loss of individual autonomy of attorney. Whereas, individual autonomy as a characteristic of the apparatus implementing judicial authority. Even the bureaucracy of attorney has not only shifted to the bureaucratic system of the civilian executive body but has led to the semi-military, which is marked by the emergence of a unity of command system. Before guided democracy, the Attorney General was indeed the supreme leader of the attorney. However, because all prosecutors are functional, there is no unity of command from the Attorney General to the High Prosecutor and Head of the Public Prosecutor's Office in handling case-bycase cases. The Attorney General only issues a prosecution policy that must be carried out and guided by all prosecutors. When it is included in the technical and material matters, the Attorney General may not even intervene.

To maintain the unity of the policy in the field of prosecution so that it can display the characteristics that are united in the mindset, code of conduct, and work procedures of the attorney. ${ }^{2}$ Thus, the prosecution in court by the attorney will not stop just because the prosecutor who was originally in charge of obstruction. Prosecution by the prosecution will continue even if it is exercised by other prosecutors as a substitute. By this principle, prosecutors are bound by one relation and work together for a common goal. The actions of one prosecutor also bind the other prosecutors. ${ }^{3}$ So it is not right, if this principle is interpreted as a unity of command that castrates the independence of prosecutors.

Soemantri said that the system is a group of parts that work together to do a purpose. If one part, then the system will not function as it should. ${ }^{4}$ This was also stated by Mardjono Reksodiputro regarding the problem of the criminal justice system. According to him the criminal justice system is run by several elements which mutually influence one another. Weakness of one element will affect the other elements. He took the example of interrelated-vessel: "a point of ink in the water of one vessel, slowly but surely will muddy the water of all vessels." 5

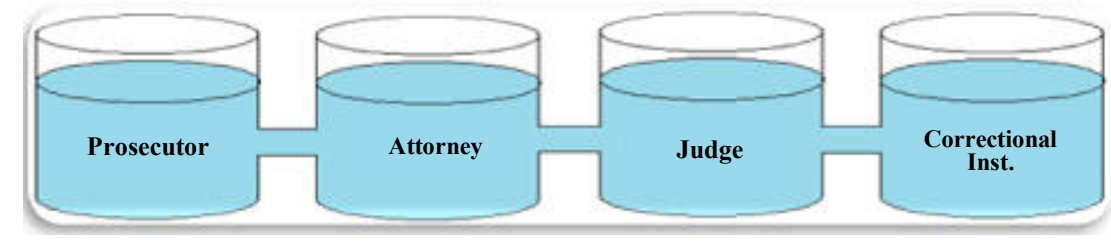

The attorney with a uniform and a command system was adopted by the communist countries. In Indonesia,

\footnotetext{
${ }^{1}$ Andi Hamzah, Perbandingan Pemberantasan Korupsi di Berbagai Negara, Jakarta: Sinar Grafika, 2005, pp. 7-8.

${ }^{2}$ Elucidation Article 2 paragraph (1) Act No. 16 of 2004 concerns the Attorney of the Republic of Indonesia.

${ }^{3}$ M.H. Tirtaamidjaja, Kedudukan Hakim dan Djaksa dalam Atjara Pemeriksaan Perkara-Perkara Pidana dan Perdata, Jakarta: Djambatan,1990., pp. 6-7.

${ }^{4}$ https://informasiana.com/10-pengertian-sistem-menurut-para-ahli/, Accessed on 24 July 2019.

5 Mardjono Reksodiputro. Kriminologi dan Sistem Peradilan Pidana. Jakarta: Pusat Pelayanan Keadilan dan Pengabdian Hukum Universitas Indonesia, 1997.
} 
this "may" mixed with the desire of the military in the New Order era to take an active role in various sectors of national life. This causes the principle of "attorney one and inseparable", to be understood as "unity of responsibility" within the framework of unity of command. This means that the leader must participate in making decisions because he must share responsibility for what his subordinates do. In spite of the ineffectiveness of harmonious institutions in preventing disparity in pursuit, what is clear is this is not in line with the position of the prosecutor as the executor of the judicial power which must be independent. Because such pattern, according to Andi Hamzah, opens up opportunities for superior intervention.

\section{An Ideal Model of Prosecutor Independence}

Currently, the independence model of attorney Indonesia is institution independence; it causes the law enforcement in Indonesia by the attorney is less professional. Even among the public appear perceptions, the attorney is easy to use by authorities as a bat against political opponents and vice versa as a protector of his cronies. It is not in line with the philosophy of a democratic rule of law. For this reason, there needs to be a renewal of the independence model of attorney in order to be able to implement law enforcement that is fair, certain and useful. Independent law enforcement will have an impact on various aspects of social life, both in terms of political, economic, social and so forth so that it will be able to realize a safe, peaceful, orderly, just and prosperous society (tata tentrem kerta raharja).

The ambiguity of the position of attorney in the constitutional structure that exists at the two legs of authorities requires very serious attention because with such a position, the attorney also has a double obligation. On the attorney side, they must implement law enforcement policies set by the government (executive), so that they are subject to instructions issued by the government. But on the other hand, the attorney exercises the duty of law enforcement independently as part of judicial authority. During this, such double duties raises doubts among the public about the objectivity of the attorney in making important decisions related to handling cases involving the interests of the authorities or the government. This problem becomes more complicated if it turns out that the authorities or governments also do not really have a commitment to uphold the rule of law. Public pessimism in relation with the objectivity of attorney in handling cases, especially when it comes to the interests of the authorities. It triggers the issuance of the idea to position the prosecutor as an independent State agency, not to become a government institution under the executive and other powers.

The idea is not quite right because the law enforcement process is essentially inseparable from the politics of law issued by the government in order to create a society that is safe, peaceful, orderly, peaceful, just, and prosperous (tentrem kerta raharja), so the government must have the tools to enforce the law, one of which is the attorney. Moreover, the responsibility of law enforcement politically lies with the government. The right way to overcome this problem is by providing a constitutional guarantee for the attorney in the constitutional structure and guarantee for the term of office of the Attorney General. A factor causing polemics about the independence and position of the attorney in the constitutional structure is due to the unclear regulation in the 1945 Constitution. Whereas many other State constitutions in the world have included prosecutors as material for the contents of the State constitution.

As reviewed by Blaustin and Lanz in the National University of Singapore (NUS) Library in the form of 20 (twenty) compilation volumes, out of 192 (one hundred ninety two) constitutions studied, as many 113 (one hundred thirteen) constitutions (93 independent State constitution and 20 autonomous regions constitutions) which explicitly regulate the position of the attorney and/or the Attorney General. This number could increase, considering that Yusril Ihza Mahendra once revealed that there are 146 the constitution that contains provisions concerning the Attorney General. Moreover, the results of the study at the NUS Library are only temporary (not the final result) because it could be that the constitutions that have been reviewed have already been subjected to amendments that are not yet known by the reviewers. ${ }^{1}$ In addition, the Attorney General

\footnotetext{
${ }^{1}$ RM. Surachman and Jan S. Maringka, Op. Cit. p. 113 et seq
} 
and the Attorney are included in the 1945 Constitution as a fact that the attorney is an institution that does not include 35 (thirty-five) institutional subjects and positions that are expressly regulated and mentioned in the 1945 Constitution.

Facts as mentioned above raises the question of how far the State considers the existence of the attorney in exercise the law enforcement function in Indonesia, compared to the functions of other institutions listed in the 1945 Constitution. Another question is whether the prosecution function carried out by the attorney is less important when compared to the two other sub-justice systems, namely the police and the court. Whereas, if reviewed from the position of the attorney in trias politica, actually the constitutional protection for the attorney independence (prosecutor) is necessary to get attention more compared the protection of the independence of the court (judge). This is because as part of the jurisdiction of justice an sich, there is no longer any doubt that the judge and the judiciary must indeed be independent. Therefore, interference in the performance of the duties of the judges will definitely get strict opposition from the experts. In addition, with only one power in place, the intervention of other powers can easily be denied. But this is not the case with the attorney, because as an institution that is under two legs of authorities that has different characteristics, the intervention of the executive institution cannot be avoided because the nature of the executive institution does indeed have a hierarchy and command. Therefore, protection of the attorney independence needs to get more serious attention.

\section{Conclusion}

Implementation of the attorney's independence must be realized in the form of an independence guarantee for the executing apparatus (prosecutor and attorney general) in exercising law enforcement duties. It is not in the form of institution independence as happened during the guided democracy up to now. The establishment of the attorney as an independent institution apparently is not directly proportional to the independence in the implementation of duties and functions in the field of law enforcement that is right under the authority of the President. When the independence of the attorney is implemented in the form of individual independence of the prosecutors and the Attorney General, it brings positive implications for the implementation of law enforcement duties.

A model of ideal attorney independence is individual independence of apparatuses, especially the Attorney General, it because as a representative institution, if the prosecutors and the Attorney General have individual autonomy so that they can exercise their duties independently, it will also lead to the perception that the attorney has independence in implement law enforcement. However, if the independence is given to the institution, it is not certain that the attorney apparatus has independence because the authority in an institution is the leader, so that leaders can intervene in their subordinates. As the executing of judicial power, the independence must be granted to prosecutors individually, but the prosecutors must subject to the policy directives as outlined by the leader because the attorney is also within the scope of executive authority.

\section{References}

Alamsari, S. Heny., Irwansyah, Muhadar, Heryani, W. (2019). Law Enforcement of Money Laundering: Case Studies on Fighting Narcotic Crime, Journal of Law, Policy and Globalization, Vol. 88, 12.

Andi Hamzah, "Posisi Kejaksaan dalam Sistem Ketatanegaraan RI", National Symposium "Hari Bhakti Adhyaksa". Held by Pusat Litbang Kejaksaan Agung. Jakarta: 20 July 2000.

Andi Hamzah, Perbandingan Pemberantasan Korupsi di Berbagai Negara, Jakarta: Sinar Grafika, 2005.

Artidjo Alkostar, "Menjaga Keselarasan antara Moral dan Hukum; Reformasi Peradilan di Indonesia." A Paper of National Seminar 'Dialectics Between Law and Moral; A Lesson of Legal Reform in Reform Era, in the $68^{\text {th }}$ Anniversary of the Islamic University of Indonesia on April 29, 2011 at Auditorium Kahar Mudzakkir, Islamic University of Indonesia, Yogyakarta, 2011, pp. 7-8.

Becroft, A. J. (2006). Children and young people in conflict with the law: Asking the hard questions. Juvenile and Family Court Journal, 57(4), 1-37. 
Bryan A. Garner, Black's Law Dictionary, ST. Paul: West Group, 2009.

Daniel S. Lev, Hukum dan Politik di Indonesia, (Translated: Nirwono and A.E. Priyono), Jakarta: LP3ES, 1990.

David Phillip Jones, "Recent Developments in Independence and Impartiality," Canadian Journal of Administrative Law \& Practice, 2002, Accessed on http://www.westlaw.com, 08 Nopember 2019.

Fitriyah Ingratubun, H. M. Said Karim, Marthen Arie, Iin Karita Shakharina. (2018). Responsive Legal Protection Against Child Abduction: A Human Rights Perspective, Journal of Law, Policy and Globalization, Vol. 71, p. 91.

Goenawan Mohamad (ed), “Menyalahkan Lilin Dalam Kegelapan”, Jakarta: ISAI, 1999, pp. 214-215.

Jimly Asshiddiqie, Konstitusi \& Konstitusionalisme Indonesia, Jakarta: Konstitusi Pres, 2005.

M.H. Tirtaamidjaja, Kedudukan Hakim dan Djaksa dalam Atjara Pemeriksaan Perkara-Perkara Pidana dan Perdata, Jakarta: Penerbit Djambatan,1990.

Mardjono Reksodiputro. Kriminologi dan Sistem Peradilan Pidana. Jakarta: Pusat Pelayanan Keadilan dan Pengabdian Hukum Universitas Indonesia, 1997.

Marwan Effendy, Kejaksaan RI: Posisi dan Fungsinya dari Perspektif Hukum, Jakarta: PT. Gramedia Pustaka Utama, 2005.

Marzuki, Peter Mahmud, (2005), Penelitian Hukum, Prenada Media, Jakarta.

R.M. Surachman, Mozaik Hukum I 30 Bahasan Terpilih, Jakarta: CV. Sumber Ilmu Jaya, 1996.

Rukmini Sen, (2010), Women's Subjectivities of Suffering and Legal Rhetoric on Domestic Violence: Fissures in the two Discourses, SAGE Publications, New Delhi.

Sofyan, Andi and Asis, A. (2013). Hukum Acara Pidana, Suatu Pengantar, Kencana, Jakarta. 